\section{EDUCATION AFTER THE WAR}

\section{By M. L. JACKS \\ Director of the Department of Education, University of Oxford}

7 HERE are to-day signs of intense activity on the whole educational front, and local advances are being planned and discussed and sometimes put into execution on many sectors. This movement is to be warmly welcomed, but it has in it certain dangers: of these the chief is that it is largely an unco-ordinated movement. This may be inevitable at the present stage of development, but it is a feature in the situation which should be brought to an end at the earliest possible moment. Until the campaign can be seen as a whole and a proper strategy worked out for carrying it to a successful conclusion, there is a grave risk of our frittering away our forces in tactical advances which are of no ultimate value, in concentrating our strength at one point and weakening it at another equally vital, and in occupying positions which are only tenable (and indeed only worth holding) if an advance is made along the whole line. It is to this advance of the whole line towards a comprehensive objective that we must devote our attention. Quo vadimus? In this article I shall endeavour to set up three direction posts and to indicate briefly to what they point. To drop the metaphor, I shall suggest three general principles which should guide our planning of post-war education, and apply them to certain practical problems.

My first principle is the principle of wholenessthe wholeness of the child, and the wholeness of his educational experience. Education viewed from this angle might be described, on the analogy of total war, as total education, and those who care to work out the analogy will find in it much that is suggestive and helpful. It has not been our custom in the past to educate our children as integrated wholes: our tendency has been rather to analyse them into wholly artificial parts, and then to try to educate these in isolation from one another. Thus we have adopted a tripartite division into body, mind and character, which has become traditional: the body we have educated (or rather exercised-by no means the same thing) on the playing-field, the mind in the class-room (and for many this has comprised the whole of education), and the character in the giveand-take of school life ; there has been little deliberate effort to educate the will or the emotions. The result has been that not only have we failed to educate the whole man and have turned out from our schools those unbalanced personalities which are such a danger both to themselves and to their fellows, but we have also not even succeeded in educating any one of the three parts; for the truth is that we cannot educate one unless at the same time we educate all the rest. "A teacher comes to grief", says Prof. Whitehead, "as soon as he forgets that his pupils have bodies."

Education, if it is to be effective, must always mean the co-education of all parts of the human personality. To take a particular illustration, physical education can never be an end in itself or limited in its objective to the body; to demand this, and to make a meaningless 'physical fitness' our end, is selfdefeating. Physical education means the education of the whole man through his body, a truth of which Plato was aware when he said that "Gymnastic" was primarily for the soul. To act on this principle of wholeness will clearly mean considerable changes in our choice of subjects and in our methods of teaching them; we shall have to make a deliberate attempt at synthesis in constructing our time-tables and in organizing our school-life, so that a day at school may become a piece of intelligible tapestry instead of the patchwork quilt which it so often is. We shall have to change our very conception of a 'subject', and perhaps give up the use of the term (and a good riddance), substituting for it the conception of an activity, and the activity of a whole human being. This human being, moreover, is a whole now, and there is a wholly right life for him to live to-day ; to provide that life is to educate him : education is not a preparation for something else, for a distant and uncertain future, for earning a living or citizenship or life, but is a whole life (and a different life) to be lived by each child here and now ; out of that life the right future will develop as the flower from the bud.

Moreover, the process must cover the whole period of childhood and adolescence; up to the age of eighteen (at least) the boy must be subject to educational authority, and if he leaves school for parttime employment in a factory at fifteen or sixteen it must be because it is there that his education can best be carried on. This is very different from the continuation school plan, under which a controlling industry will let off an employee for so many hours a week to continue his education. Industry can play its part by friendly co-operation with the school, by stressing the educative side of its young employees' work, and perhaps by the establishment of works' schools. Such an educational scheme implies a social revolution; but education and society are so closely interwoven that the revolution which we all see to be necessary in one cannot be carried out without a parallel revolution in the other.

So much for wholeness. My second principle is that of comprehensiveness. The connotation of the word 'education' has immensely widened since the days when it stood for little more than the three $R$ 's, and it is widening every day. We now know that education means much more than teaching even a vastly increased range of subjects; it means the provision of everything a child needs for the discovery and full development of all his potentialities-physical, intellectual, emotional, moral and spiritual. Nutrition and health, milk and meals, rest and sleep, cleanliness and clothing, the encouragement of aptitude and creative skills, the growth of emotions into valuable sentiments, training of the rsthetic sense and of social attitudes, vocational guidance; all these are properly part and parcel of the educational process for all boys and girls, and not only for those who, by reason of home circumstances, seem to stand particularly in need of them; it is very often those who seem to need them least who do in fact need them most, and none of these elements in the educational process must be tarred with the brush of State-charity.

There must be, moreover, a new marriage between the cultural and the technical, and that false and unfortunate dichotomy must be ended in a new conception of twentieth-century culture. The old dividing line between a 'liberal' and a 'vocational' education (never a very clear one) must be erased wherever possible, and we must so teach our more specifically cultural subjects that their vital relationship with the technical may be recognized, and so teach our 
more specifically technical subjects that their full cultural possibilities may be realized. The curriculum, moreover, must be widened. There has been a rapid movement in this direction during the past thirty years, a movement to which evacuation experiences have given an added drive; many schoolmasters, evacuated to a new environment and compelled by the exigencies of war to devote the time of their pupils to activities which have never hitherto fallen within their purview, have found, to their surprise, that these activities are often more educational than the class-room subjects whose time they have usurped. It is to be hoped that this lesson of evacuation will never be forgotten. But a wider curriculum can only be maintained if it is accompanied by greater freedom of choice on the part of the boys and girls for whom it is provided. We need a much greater variety in post-primary education, whether this takes the form of a greater variety of schools or a greater variety of 'sides' within the same school. I can visualize a postprimary education in the future of which the staple constituent will be book-learning as in the secondary school with which we are familiar, and at the other end of the scale an education in which book-learning will be almost non-existent, with infinite gradations in between: I visualize schools which are more like clubs, new types of boarding-schools (on the lines of the present camp-schools), schools which are day schools up to a certain age and boarding-schools beyond that, and many other varieties. Only in such a variegated field shall we be able to attain that 'equality of opportunity' in education which is to-day a popular slogan, but like most slogans very illthought out. It does not mean equality of opportunity to attend a certain type of school enjoying a fictitious prestige, or equality of opportunity to go to the university. It means that every child should enjoy an equal opportunity with every other child to receive the right education for him, and that means that we must have available types of education to meet the needs, intellectual, moral, physical, and spiritual, of all children.

My third and final principle is that, in a far more real sense than ever before, the schools should serve the community, and the community the schools. The community demands that the product of education should be the good citizen; the individual demands the development of a unique personality. These demands are often regarded as contradictory; they are in fact complementary, for the fully developed individual is the life-blood of democracy, and the best citizen is the man who has been given the opportunity, and has taken it, to become his best self. This truth is more likely to be appreciated, and the duty of the community to the school and of the school to the community is more likely to be performed, if there is a much closer association between the two. On one hand there should be no schools outside the national system. This does not mean standardization, or the reduction of all schools to the dead level of the few categories which we know; for the national system itself is capable of expansion to embrace a much wider variety of schools than it does to-day, and there should be room within it for all those diversities of educational life and experiment represented by schools which are at present independent of public support: given public support, they must, of course, be open to all who can profit by the education they offer, and our ideal should be schools common to all classes but diversified in type.

The two essential freedoms to safeguard are the freedom of the parent to choose his child's school, and the freedom of the school to choose its pupils, both freedoms being exercised within wide limita. tions. This association between school and com. munity can be further fostered by the encouragement within the school itself of realistic social studies. I do not mean by this courses in civics or current affairs, though these may have their importance. But citizenship is best learnt by practising it within the school community, and its significance can best be appreciated by the study and use of the community immediately outside the school walls. The locality should, in fact, be the first text-book of every school. If that can be done, there will be less danger of that community-sense which many of our schools foster (and particularly our boarding-schools) stopping short, as it so often does, at a school-communitysense, and a bridge will be built (one of the most difficult bridges to build) between school and 'real life'. That should be the beginning of an outward movement which will end in the world-eommunity claiming the allegiance of the world-citizen.

Finally, the 'walls of partition' must be broken down from the outside as well as from the inside, and if the school is to go out to the community, the cornmunity must come into the school. To some extent this is being done, and it is symbolical of the change that, whereas in the nineteenth century schools were surrounded by high walls and locked gates, to-day they are commonly built open to the streets and the gates are rarely shut. But the flow of traffic through this open gate is not yet as free as it should be. There is no reason why the industry and the craftsmanship of the neighbourhood should not find their way into the classroom and display their wares and expound their ways of life there-invaluable recruits to the teaching profession; there is no reason why other recruits should not be found among representatives of the local authority and of the professions; there is no reason why the schools themselves should not become community-centres for education, providing classes and courses and cultural activities for children in the day-time and for their parents in the evenings. In these ways social studies would become a real and vital element in the curriculum, and the association between school and community would be complete.

Much has necessarily been left unsaid in this article. No mention has been made of the universities or of adult education : the whole field of religious education has been left unexplored-if explored, it would be found to affect profoundly not only the curriculum, but also the whole organization and administration of the school; and nothing has been said about the training of teachers or the relationship between teaching and other forms of youth service. But I hope I have succeeded in erecting certain pointers to the education of to-morrow.

\section{STRUCTURE AND ROTATION OF GALAXIES}

A. SUCCESSFUL and well-attended symposium A on the structure and rotation of our own Milky Way system and of external galaxies was held at the rooms of the Royal Astronomical Society in Burlington House on July 10.

The discussion opened with a contribution by Dr. A. Hunter on interstellar absorption and the scale of 